\title{
Review of The End of Desertification? Disputing Environmental Change in the Drylands by Roy H. Behnke and Michael Mortimore
}

\author{
lan Scoones
}

\author{
Book details \\ Roy H. Behnke and Michael Mortimore (editors) \\ The End of Desertification. Disputing Environmental Change in the Drylands. \\ Springer-Verlag, Berlin (2016). \\ 560 pp. ISBN 978-3-642-16013-4. £126 (hardback)
}

Keywords: Desertification, Land degradation, Non-equilibrium ecology

Tales of desertification across the world's drylands are a recurrent theme in policy discourse. This book takes issue with many of the assumptions around desertification, with cases ranging from Central Asia to West Africa to the Mediterranean to the American West. It is edited by Roy Behnke, an anthropologist with deep knowledge of pastoral areas in North and Southern Africa, West Asia and more, and Michael Mortimore, sadly now late, a development geographer, who knew a huge amount about the drylands of Africa, and particularly northern Nigeria.

There are 20 top quality chapters, coming from diverse disciplinary backgrounds and a range of cases. Early chapters examine the Sahelian 'desertification crisis' from the 1970s, drawing lessons that challenge the much-repeated simplistic interpretations. The cumulative argument is powerful, but will policymakers listen? The myths of desertification have a long history. Ideas of desiccation and desert advance were framed by colonial science and informed by the narratives of the 'dust bowl' in the USA, as discussed by Diana Davis in her chapter on the history of desertification thinking. Yet, whether from long-term environmental monitoring, aerial and satellite photography, ecological modelling or local knowledge and field observation, the standard narratives

Correspondence: i.scoones@ids.ac.uk

ESRC STEPS Centre, Institute of Development Studies, University of Sussex, Falmer, Brighton BN1 9RE, UK

\section{Springer Open}

have been found severely wanting, and, as Stephen Prince argues, basic definitions and systematic mapping are absent.

Challenges to desertification myths, and simplistic equilibrium approaches to rangeland dynamics based on Clementsian succession ecology, have of course long been made, as Roy Behnke and Michael Mortimore discuss in the opening chapter. For example, Jeremy Swift and Andrew Warren wrote classic papers in 1977 for the UN Conference on Desertification, but both were ignored. Stephen Sandford's important book on pastoralism made many similar points, based on a mountain of evidence (Sandford 1983). Building on the insights of Jim Ellis and the research team working in Turkana, Kenya (Ellis and Swift 1988), the Woburn conferences in the early 1990s resulted in two books that made the case for a new paradigm for African rangeland management (Behnke Jr et al. 1993; Scoones 1994).

This consolidation of empirical data within a new conceptual frame provoked lots of new work (Vetter 2005). For example, the science of remote sensing and the application of geographical information systems, supported by long-term ecological monitoring, have enhanced spatial understandings of environmental change massively, reinforcing the argument against a linear view of desertification and a more dynamic view, as illustrated in excellent chapters by Stefanie Hermann and Tene Kwetche Hop, as 
well as Pierre Hiernaux and colleagues. As Alessandra Giannini outlines, 40 years of climate modelling in the Sahel generates a complex picture of drought and desertification, challenging the standard media narratives discussed by Mike Shanahan. As the case studies in the latter part of the book show - from southern Ethiopia to Patagonia to the Bolivian Andes to China - degradation of elements of dryland landscapes certainly occurs, but it is a complex and variegated process, not amenable to simple intervention or sweeping policy.

\section{Science and the politics of policy}

Unfortunately, much of this accumulated evidence has been ignored, and the narratives of desertification persist. Why is this? The relationship between science and policy is not linear: new data leading to a transformation of scientific paradigms does not necessarily result in a change in policy and practice. Evidence and policy, despite the rhetoric around evidence-based policymaking, are not neatly linked. Why is it that, even when scientific evidence is seemingly incontrovertible, then shifts in policy discourse and practice do not happen? As Lynn Huntsinger shows from the USA, a lot is to do with the power and stickiness of narratives - and so the politics of knowledge in policy (Keeley and Scoones 2003). Other forces are at play, beyond the slow, patient and rigorous accumulation of knowledge.

From the 1990s, there were some in policy and practice circles who accepted the non-equilibrium view, questioning the simplistic versions of desertification across the drylands. But this was sometimes a naïve advocacy for 'indigenous' systems - valorizing transhumance or nomadism in a simplistic, romantic way. Ignoring challenges of land management, and inventing an ideal 'tradition', is not the answer. Mainstream institutions and policy, while often playing lip service to changes in the growing critiques of the desertification framing, did not take the argument for rethinking seriously though. Paradigms may have shifted in science, but not in policy.

Even today, and despite fantastic books like this one, it is amazing how often you see projects, documents, statements and plans repeating the same old story, as if debates in science over decades had never happened. The annual 'World Desertification Day' is an occasion for repeating myths, while signatories to the UN Convention to Combat Desertification regurgitate the arguments in every national submission.

So why do things not change? One reason is that new ways of thinking only permeate through slowly via training, curriculum revisions and generational change in professions. Incumbent power also resists change. This reflects the conservative nature of institutions and professions. While the science of rangelands has shifted, old ideas stick among field-level departments, aid agencies and their officials. It is perhaps not surprising when there is fast turnover of staff, poor resourcing, and institutional inertia and limited learning.

But it is not only inertia. There is also a more active politics of resistance. 'Seeing like a state' (Scott 1998), rather than a pastoralist or dryland farmer, has many consequences, as states attempt to control, manage and discipline such marginal areas (Catley et al. 2013). Programmes of sedentarization, fixed water points and often draconian environmental measures to combat desertification are regularly promoted, supported by international aid agencies, as Camilla Toulmin and Karen Brock explain for the Sahel.

As Mike Mortimore and Yamba Boubacar explain in their chapters, a more decentralized people-centred approach that has its focus on livelihoods and poverty, not environmental control, has much more likelihood of success. An alternative science of the drylands however is too often a long way from the discussion. Many interventions are about the exertion of state power and control, and the persistent and insidious power of incumbent institutions, hooked into a narrative that will not budge, and continues to be supported by international agencies.

In my view, one of the most mistaken moves in this field in the last 25 years was the creation of the UN Convention to Combat Desertification. As a concession to African states in the post-Rio deal, it has not had the traction of the conventions on biodiversity or climate change. The desertification narrative suited many purposes, and the critiques first raised in UN circles in 1977 were not heeded. The rhetoric is more sophisticated these days - participation, inclusion, cooperation, local knowledge and a wider view of land degradation are all part of the mix. But the fundamental frame remains. Many comment pieces, policy briefs and communiques repeat those tired and long-disputed statistics on land degradation or nutrient deficits. Too often it is spurious science and economics presented as fact, supporting a narrative that we thought had been dismissed decades ago.

\section{Embracing uncertainty, working with variability}

As science over many decades has shown, and this book emphasizes again, non-equilibrium ecology is a useful way of thinking about complex, highly variable dryland ecosystems - especially in the context of climate change (Scoones 2004). In particular, it provides a useful basis for challenging simplistic, linear desertification narratives. The key lesson is that there is no simple, standardized solution to dryland development, especially with fast-changing climatic, economic and political contexts; flexibility, agility and 
adaptive management are key - lessons that seem to have been long learned in Australia, as Mark Stafford-Smith explains in the final chapter.

Particularly worrying in the last 10 years has been how the desertification narrative has been reinforced by debates about climate change. Again, against much evidence, climate change is simply taken to mean a secular shift, and so increasing desiccation, leading to land degradation, desertification and conflict. In fact, much climate science points to processes of increasing variability and uncertainty, not secular change. As Tor Benjaminsen shows, the link between climate change and conflict is not straightforward. The satellite image data shows 'deserts' expanding and contracting over time in a complex patchwork, and not simply advancing, as various chapters discuss.

A focus on non-equilibrium, dynamic systems points to a different response - one centred on flexibility, adaptive management, responsive care and resilience, not control and technocratic intervention. The desertification narrative promotes a control-oriented response - with destocking, 'green belts', forest planting and engineering solutions dominating - rather than one that embraces uncertainty, and makes productive use of variability, as in the non-equilibrium paradigm. But of course, realizing the alternative paradigm is difficult. Institutional biases, procedures and routines reinforce control, especially when funding agencies and governments have fewer and fewer people in the field, connecting with the real world of the drylands.

So will this book make a difference? I hope so, but it will require connecting the evidence so well laid out in this book to a wider debate and shifting the underlying politics of knowledge and practice that underpin the desertification narrative. Evidence, as we have seen, is not enough. A new, practical narrative realized in action on the ground is required - translating the science of 25 years or more into new ways of doing things. As Mark Stafford-Smith urges, in the last sentence of the book, 'Let us find a positive narrative for the drylands'. This book is an important part of this project, but only a first step. Let us hope its contents are widely read and that it is made available for free at a much cheaper price to all those policymakers and donors stuck in the old paradigm. Only then will we see the end of desertification talk.

\section{Acknowledgements}

Not applicable

Authors' contributions

is carried out all the work. The author read and approved the final manuscript.
Consent for publication

Not applicable

Competing interests

The author declares that he has no competing interests.

\section{Publisher's Note}

Springer Nature remains neutral with regard to jurisdictional claims in published maps and institutional affiliations.

Received: 13 August 2018 Accepted: 16 August 2018

Published online: 01 October 2018

\section{References}

Behnke, R.H., Jr., I. Scoones, and C. Kerven, eds. 1993. Range ecology at disequilibrium: New models of natural variability and pastoral adaptation in African savannas. London: ODI.

Catley, A., J. Lind, and I. Scoones, eds. 2013. Pastoralism and development in Africa: Dynamic change at the margins. London: Routledge.

Ellis, J.E., and D.M. Swift. 1988. Stability of African pastoral ecosystems: Alternate paradigms and implications for development. Rangeland Ecology \& Management/Journal of Range Management Archives 41 (6): 450-459.

Keeley, J., and I. Scoones. 2003. Understanding environmental policy processes: Cases from Africa. London: Routledge.

Sandford, S. 1983. Management of pastoral development in the Third World. Chichester: Wiley.

Scoones, I. 1994. Living with uncertainty: New directions in pastoral development in Africa. Rugby: IT Publications.

Scoones, I. 2004. Climate change and the challenge of non-equilibrium thinking. IDS Bulletin 35 (3): 114-119.

Scott, J.C. 1998. Seeing like a state: How certain schemes to improve the human condition have failed. New Haven: Yale University Press.

Vetter, S. 2005. Rangelands at equilibrium and non-equilibrium: Recent developments in the debate. Journal of Arid Environments 62 (2): 321-341.

\section{Submit your manuscript to a SpringerOpen ${ }^{\circ}$ journal and benefit from:}

- Convenient online submission

- Rigorous peer review

- Open access: articles freely available online

High visibility within the field

- Retaining the copyright to your article

Submit your next manuscript at $\boldsymbol{\nabla}$ springeropen.com 